\title{
Social and Cultural Barriers to Effective Agricultural Extension Service Delivery in Nigeria
}

\author{
Ifeoma Q Anugwa* \\ Department of Agricultural Extension, University of Nigeria, Nigeria
}

Submission: January 17, 2018; Published: March 21, 2018

"Corresponding author: Ifeoma Q Anugwa, Department of Agricultural Extension, University of Nigeria, Nsukka, Enugu State, Nigeria, Tel: +2348065435735; Email: ifeoma.irohibe@unn.edu.ng

\begin{abstract}
The role of an agricultural extension worker in any nation involves disseminating information on agricultural technologies and improved practices to farm families and ensuring farmers' capacity building through the use of a variety of communication methods and training programmes. For success to be recorded in extension service delivery in rural areas, the extension agent needs to understand and be sensitive to social and cultural factors existing in the area. However, by carefully selecting what he encourages farmers to do, and how to convey the message, the effects of social and cultural barriers to extension service delivery can be reduced. This mini review examines the social and cultural barriers to effective extension service delivery in Nigeria. Some barriers highlighted were respect for tradition, belief in culture, traditional ceremonies, etc. Therefore, extension programmes aiming at introducing new methods of farming should take into account the possible effect on the whole society and its culture, and not merely the technical results of the methods recommended.
\end{abstract}

Keywords : Agricultural extension, cultural barriers, service delivery, social barriers

\section{Introduction}

In a country's agricultural development process, agricultural extension workers are expected to help farmers to identify and analyse their production problems, make them become aware of the opportunities for improvement in farm yields in order to obtain increased income and obtain a better standard of living. The role of an agricultural extension worker involves disseminating information on agricultural technologies and improved practices to farm families and ensuring farmers' capacity building through the use of a variety of communication methods and training programmes. It is through education and communication that agricultural extensionists are able to bring changes in farmers' knowledge, attitudes and skills which help to put farmers in a frame of mind that is conducive for adopting proven agricultural innovations [1].

Van den Ban \& Hawkins [2] state that the major role of agricultural extension in many countries, including Nigeria, in the past was seen to be transfer of new technologies from researchers to farmers. Now, it is seen more as a process of helping farmers to make their own decisions by providing them a range of options in a given innovation from which they can choose, and by helping the farmers to develop insight into the consequences of each option. However, farmers' attitude and desires are influenced by the socio-cultural background of their societies and this affects their acceptance or rejection of an agricultural innovation. An extension agent will be more effective in his service delivery if he understands the social and cultural background of the farmers with whom he works. He will then be better able to offer advice that fits in with the culture of the society, and he can use the structure and culture of the society to the benefit of his work. It is useful, therefore, to examine the main socio-cultural barriers to effective extension service delivery for agricultural development in Nigeria.

\section{Social and cultural barriers to extension service delivery}

Although cultures and social structures are always changing, the process is often slow. In the short term, there will be features of society and culture that may act as barriers to agricultural development. It is important that the extension agent be aware of the existence of such barriers and to take them into account in his service delivery. Savile [3] identified such barriers as the following:

Respect for tradition: Many rural societies look upon new methods with indifference and sometimes with suspicion. Respect for elders often results in the attitude that the old ways are best. Farmers not only fear the unknown and untried but they also fear criticism for doing something different from other farmers. In such situations, the motives of extension agents and others seeking to promote change can often be misunderstood. 
Village people may think that the extension agent is introducing changes to benefit himself. Such attitudes explain the behaviour of farmers who seem to agree that a new method is good but are not prepared to put it into practice.

Belief in one's own culture: Members of all societies believe that their way of life is best. "These new methods of farming may be all right for some people but they are no good for us." This attitude results in reluctance to try something new. "How can it be better than our way?" and "We know what is best for us" are reactions that extension agents may meet in opposition to suggestions for change.

Pride and dignity: Farmers may be too proud to practice ways of farming that could result in other farmers looking down on them. For example, they might be too proud to carry cattle manure to the fields. Many young people leaving school look down on farming, even though some successful farmers earn more than most government employees and schoolteachers.

Relative values: Extension agents often emphasize the improved yield or cash return that can be gained by adopting new farm practices. However, farmers may value taste, appearance or some other factor more than the level of output. They may also value their leisure time so highly that they are not prepared to work longer hours on their farms. Certain improved varieties of maize have been rejected by small-scale farmers in Nigeria because of their poor flavour, even though they have shown a much better yield than local maize. Farmers and their families have to eat what they produce as well as sell some of it, so taste and cooking quality are very important.

\section{Responsibilities and social obligations}

Individuals within a society or a kinship group have responsibilities which they are expected to carry out. People who avoid such responsibilities anger other members of the society. As an individual's income increases, so obligations to society or family increases. The more money a farmer earns, the more help kinsmen will expect. This can be a very serious barrier to change if the individual sees little advantage in improving his or her position because there is not much personal benefit from the improvement. However, this may be overcome by concealing wealth, by distributing cattle among friends, or by burying or banking money so that relatives can be told that no money is available to help them. This may result, for example, in a farmer being reluctant to carry out visible farm improvements such as fencing, buying farm implements and other things which might suggest to kinsmen that the farmer is wealthier than they think.

\section{Traditional Ceremonies}

Ceremonies such as weddings, funerals and religious festivals can take up so much time that the farmer may be unable to work to the maximum efficiency. The farmer is, therefore, unlikely to adopt new methods, which, while they might increase income, would mean that more time had to be devoted to working the farm and less to ceremonial and social obligations. The extension agent needs to understand and to be sensitive to these potential social and cultural barriers to change; however, by carefully selecting what he encourages farmers to do, and how to convey the message, their effect can be reduced. Winning the support of traditional community leaders, for example, may lessen the effects of tradition. Furthermore, by making sure that popular food crops are included in agricultural programmes and that the recommended varieties are acceptable on grounds of taste and cooking quality, the extension agent can increase the likelihood of his advice being accepted. Extension programmes aiming at introducing new methods should take into account the possible effect on the whole society and its culture, and not merely the technical results of the methods recommended.

\section{Conclusion}

In Nigeria, Agricultural Development Programs (ADP) plays the role of extension and delivery services in the agricultural sector. ADPs liaise with the research institutes for improved technologies in order to effectively deliver services to the farmers. For a success in extension service delivery in rural areas, the extension agent needs to understand and be sensitive to social and cultural factors existing in the area. However, by carefully selecting what he encourages farmers to do, and how to convey the message, the effects of social and cultural barriers to extension service delivery can be reduced. Winning the support of traditional community leaders, for example, may lessen the effects of tradition. Furthermore, by making sure that popular food crops are included in agricultural programmes and that the recommended varieties are acceptable on grounds of taste and cooking quality, the extension agent can increase the likelihood of his advice being accepted. Extension programmes aiming at introducing new methods of farming should take into account the possible effect on the whole society and its culture, and not merely the technical results of the methods recommended.

\section{References}

1. Agbamu JU (2005) Problems and prospects of agricultural extension service in developing countries. In: Adedoyin FS (Ed.), Agricultural Extension in Nigeria. ARMTI, Illorin, Nigeria, pp. 159-169.

2. Van den Ban AW, Hawkins HS (1998) Agricultural Extension, Second Edition. Blackwell Science Publication, Oxford, USA, pp. 267-268.

3. Savile AH (1965) Extension in Rural Communities. Oxford University Press, India. 
This work is licensed under Creative Commons Attribution 4.0 License DOI: 10.19080/ARTOAJ.2018.14.555930

\section{Your next submission with Juniper Publishers will reach you the below assets}

- Quality Editorial service

- Swift Peer Review

- Reprints availability

- E-prints Service

- Manuscript Podcast for convenient understanding

- Global attainment for your research

- Manuscript accessibility in different formats ( Pdf, E-pub, Full Text, Audio)

- Unceasing customer service

Track the below URL for one-step submission https://juniperpublishers.com/online-submission.php 